\title{
The Practice of the Communicative Learning in the Albanian 9- Classes Educational System. New Techniques that Require Not Only Spread but Also Specialized Teachers
}

Linda Ciftja

\section{Introduction}

The urge to develop the subject of this article has been the desire for a scientific research upon the methodologies that perform the communicative learning today in the 9-classes educational system and their application in our schools. The educational process is a lively phenomenon. It has evolved through years everywhere in the world thanks to multiple fruitful educational policies. The same has happened even in our country. The practices have shown us that nowadays in Albania and many European countries the communicative learning is the most successful one.

\subsection{What does communicative learning mean?}

The communicative learning is defined as an active involvement of the student during the process of the lesson. This kind of learning is about the student being not only a simple reproducer of the school material (information) but also doubting, examining, creating, choosing, interpreting, debating facts, data or ideas. The learning in this case is performed in an interaction that aims the student's involvement and all inclusion during the lesson.

The terminology "communicative learning" is understood by using the intuition more than being defined with other ultimate terminologies, but however it has been part of the lesson and especially essential part of the foreign languages classes in which unlike other subjects has been implemented in the best part of the class, for a specific part of the foreign language is the practice of speaking and its perfection through ways of communication as a specific aim (orally and in written form).

In model classes based on the traditional model, the best part of the lesson is accumulated by the student through listening to what the teacher explains. But isn't it necessary for the student to exchange ideas, to ask, research, think (even out loud), to conclude, to feel free (through speaking, writing, colors, etc) apart from listening only?

According to the Swiss psychologist Zhan Piazhe a person learns by understanding the world around, by making the concepts work. During this process the person changes the old concepts so in this case he expands his ability to better understand the future. Piazhe's ideas were about the fact that as the student might have unclear concepts or even incorrect ones the teacher should start the teaching by pointing out these existing concepts which are clear to them. Then he can perform his lesson through questions and make the students clear the aim of the lesson. These ideas were selected in that way that they could be more fruitful and practical for the teaching process. They aimed the urge for the student's involvement. So they motivated the student in question making. Firstly these questions are made to get the information they did not understand. Then the teacher teaches the student how to make the questions (how to formulate it), how to research, how to examine an information etc.

In this way the student naturally steps toward the active-communicative learning without any artificially forced involvement. In fact all of these make the student perfect the skills to learn, educate the ability to reflect and to concretely implement the theoretical instructions. This makes the student go away from a routine class and approach toward a freeand-easy and more fruitful class, where a communicative relationship is always found.

It should be reminded that the communicative learning, just like an active learning, does not underestimate the old method of learning but elaborates it by aiming to avoid those steps in which nothing is practiced, nothing could be build by the student, where you find elements that lead toward a passive profile of the student, the profile of simply a listener and applicant.

\section{The Priorities Toward Communicative Learning Based on the Class Monitoring}

- The practices of the teaching process have confirmed that the communicative teaching is the most complete and successful process nowadays. The studies confirm that in modeled classes to this kind of learning not 
only reproduces information but also analyses what it teaches. So the student is actively involved during the entire process and even outside of this process.

- The student and the teacher through this kind of learning go far away from the routine of the monotonous preset models. Every class is something new that cannot precisely be foreseen because many times the student himself and the results of their work interact or change planned rubrics about the process of the lesson. The lesson performed based on the communicative model is not easily forgotten, firstly, for the important fact that the student is the center of the process, the action, the thinking, the word, the collective task and of the independent individual research modeled according to their skills.

- In traditional classes the teacher verbalizes the information through the process of note taking of those displayed (written, demonstrated) on the board or through speaking. It is proved that the student can remember only $10 \%$ of the content of such lesson.

- In the active communicative learning the student results to be more independent and that every student according to their skill is able to work, to find himself and positively get evaluated. At the same time he can evaluate and judge his friends' works.

- Nowadays the most successful classes are exactly those that stimulate the student to think by themselves and get involved in the critical thinking which apart from the other things makes possible for the student to have a long term memory of the information.

- The teacher who applies methods of a communicative learning makes an effort to create an environment in which the student could be able to learn and reconstruct the new information and new main knowledge and tries to put them into practice (it should be pointed out that the student is supposed to be an intelligent participant in the creation of the new knowledge that might require the student to work in an independent manner with the vocabulary apart of all the other tasks)

- The teacher can apply the explanation of new concepts, principals and methods, visual aids, demonstrations, etc, easily integrated in the class presentations (the tasks they fulfill under his instructions)

- This kind of teaching process can develop the ability to use the given knowledge only by the teacher and also very successfully in the organizing of small groups.

- Many reports state that the communicative learning is a long term learning, not easily forgotten, for he is part of many activities that include starting from the discussion, research, argumentative writing, fast and free writing up to the discovery of unspotted talents at the student. It has been proved that in classes the student is able to remember $50 \%$ of the content of the lesson and he is more interested toward a self education, which means that he learns how to monitor and discuss his own lesson. In a certain way the student becomes ' $a$ sponge' that continuously soaks knowledge and expands skills.

- Unlike the traditional model, in which the student was an object where you would deposit concepts and information, in the learning that has the communication as an essential element of the obvious active participation, apart all other steps the student is rewarded even for skills like: good short term memory and good reading skills, too. The studies confirm that in model classes according to this kind of structure, the teaching results to be more fruitful and complete which means that the student can think out loud of what he is learning about.

- The active-communicative teaching requires the student to find the possibility to actively get involved in conversations even during the listening phase, the writing and reading process to come up to their reflection upon a content, an idea, a matter or a worry toward a certain subject that is spotted for a considerable level of difficulty.

- The students part of an active-communicative learning are in fact much more than simply a listener even when they are listening to some new information, because their attention is found in a higher level. At the same time, through the listening technique, they try to elaborate also foresee actions upon what they listen and present and protect them through speaking and writing techniques. They can be defined as constantly engaged in the activity even when they are in the listening process.

- It is proved that the students as a participant in the active learning of the communicative kind are also more attentive than the students who are passive receivers of the information. This is due to the student's active mind which foresees 'to break' the monotony that comes due to the regular flow of the process. He is constantly in activity (even when he reads, writes and discuses).

- He foresees activities afterwards, so he focuses with much more desire on what he is listening to and which he foresees it as a temporary activity or process.

- The active student of this kind is he who worries if he could choose which the correct part of the information he 
is introducing is. He is preoccupied about his choice. He tries to reflect and judge upon it even when this information is totally part of the new subject.

- The active student of this kind is constantly preoccupied about the time. He is the center of multiple activities that require his participation, involvement that gets motivated by the teacher. Time for the completeness of all the activities is never enough for the student who is constantly busy with activities. He often leaves aside unfinished activities because of the lack of time. To him there is always a limited time. This in fact makes him to think even when the time is off. His mind is always totally involved in the learning, projects for the presentation of his works and always in search (even irresponsible ones) of the correct forms of communication that urge him to try to perfect the communication by correctly mastering the substantial terminology.

\section{What Does Not the Communicative Learning Help?}

- One of the very present barriers found in the classes according to the active schemes just like that of the communicative kind is that there is a lot of material to be covered by the teacher and the student too. Apparently with less new material and much more time for reinforcement (in simple manners or even the most complicated ones) would lead toward the strengthening of a greater desire to teach the students.

- There are methods which even though practiced with great values in one direction, risk not being successful in another aspect. For instance the method of thinking out loud although urging the students to not fear and freely express their arguments to the others, risks to waste a considerable time for extra long reasoning with no result for the student and far worse when they are totally wrong or in complete deviation from what is required, a result this as a misunderstanding of the requirement.

- This kind of learning does not properly help the student who does not master enough the educational language (educational speech). The educational speech describes concepts which cannot be easily demonstrated through illustrations. It is often used to describe abstract, unperceiving ideas like: the reasons of a hypothesis, interpretation of a character's actions, etc.

- The quality of the students' involvement in the class beyond simple verbal techniques in the ninth class is worse in comparison to the preceding classes, because this class coincides to the first year of our past high school educational system. The process of the inclusion of class nine in the program once issued for the preuniversity educational system is a premature one. Our teachers of the nine class system, for different subjects which unfortunately are more difficult in this class (literature, chemistry, biology, physics), go through many difficulties when using these programs and this affects directly the student. They are in need of an intensive supervision and training, a certificate provision, etc. On the other hand this does not enable the students, who have difficulties, to better understand the content and have clear ideas about the concepts that are used.

The learning objectives start from the lower level to that of a higher standard. Based on this fact we have the rating of the levels of the processes which cannot be accomplished by every student because they are related even to the skills and expressions they possess. They introduce a pecking order. Following this order we have the process of remembering (this belongs to the lowest level of the learning) then we have the understanding, the practice, the analyzing, the evaluation and to the highest level that exits the creation. Perhaps not all the steps are covered by the students of one class in some certain lessons according to the communicative learning because some of them like: thinking out loud or speaking through gestures would require students who are not lower to the base level. Perhaps to them would be more helpful the application of the methods that are supported by multiple intelligences, that offer the students support, outlines, understanding and the necessary effort to get to higher levels of understanding and more complex levels of thinking and expressing ideas.

\section{Which are the Techniques of the Communicative Learning that are Usually Used in our 9 Class Educational System in the City? (Some Theoretical Schemes)}

As it is already known in the traditional frame of the learning the teacher is the center of the class. He is the one who leads the class through activities from which the most focused ones are those that deal with the reinforcement of the lesson. This is accomplished through the special review of the information received by trying to stick to the maximum correctness as it is taught by the teacher including even the way of presenting it. Think of one, two, twenty students who repeat exactly the same information given by the teacher. They would resemble a tap that is on and off by the controlling cock. 
What would happen to the children who would exactly reproduce what has been taught by their parents once and with the same eagerness require the reproduction of this information by their children and then these children ask the same to their children?

They would be part of a vicious circle, closed toward development; grandchildren and grandparents carrier of the same knowledge that does not know development. This tendency of the application of the traditional method is a barrier to the development of the variety of thinking, other manners of thinking, other manners of seeing, other manners of acting. Many teachers partisans to the traditional learning, even nowadays think that techniques like gestures, songs, games are useless activities and sometimes ridiculous that loose the importance and of the learning process. The students who have difficulties learning or those defined as 'low progressed' are always hiding behind the others. Even though they are under their friend's supervision when it is time to be an active part in the lesson they hide out.

All of the above make the traditional method an old manner of learning and not giving results, but on the other hand having in mind that in Albania there are still rural areas where the lesson is taught in collective classes makes you doubt either applying modern learning methods or not. We would even say that apart from the traditional method no other method can be applied in these cases.

There are enough theoretical materials nowadays which treat theoretical schemes of the development of many methods among which the active communicative learning would be developed. They aim, as mentioned before, to have a student centered class. It is the student who is aimed to have the lesson, he is the one who would develop and sometimes create the activities, he is the one who would build up reasoning bridges, who would create relationships, would get oriented to sum up, to foresee, to discuss, to ask logical questions and at last to order and analyze all those that could be assigned as possible in application and appear as successful. Many of them require special conditions or specific subjects in which they can be applied. For the effective selection it is up to the teacher to decide.

-Every method is applied in three phases during the class: that of the prediction, when the student is focused on the subject required to have new ideas, knowledge construction, when the student reviews his predictions and disciplines his own opinion and the last one that of the reinforcement, when the student has understood the ideas and still has something to do. These steps are part of all methods. It should be kept in mind that all methods should be practiced in that way that they would be acquired to be well used. The teacher must have clear ideas about the position of each phase and to what he is going to achieve with the application of the activities. The success starts from the correct plan of the lesson.

\subsection{Lesson plan}

A notebook where the student writes down his reactions toward the things he learns about. The emphasis is mainly on personal reactions and thoughts related to the text rather than the notes about the text.

\subsection{The two part lesson plan}

It is used as a reaction in written form toward a read passage. The sheet of the notebook is divided in two columns, one used to write down the statements from the text and the other for the reader's comment about that statement.

\subsection{The three part lesson plan}

It's a technique that makes the student reflect on the experiences he had in the activity of the experienced learning which is a method to connect the experiences of the readings with the discussions in the class.

\subsection{The specification paper}

The list of all the steps included in writing an essay

\subsection{Semantic map}

This is the graphical organization of the ideas according to the hierarchy.

\subsection{The characters' map}


This is a graphic where relationships among characters are shown. It is used as a reinforcement activity where the student takes notes in order to find diversity and connection among characters.

\subsection{Common research}

This is a method that is used to have discussions about a critical thinking, an independent judgement, from which the student comes up to conclusions.

\subsection{Pencils in the middle}

This is a technique that helps the student to equally share the time in order to collaborate with each other in a group.

\subsection{Reading/ Pair summary}

This is a collaborative activity, where a pair of students reads a text and asks each other questions about it.

\subsection{Reading and questions}

This is a mutual activity where the students read a text, ask questions about the text and answer these questions.

\subsection{Move/Stop/Create in pair}

This is a collaborative activity where the student moves around the class and stops where the teacher asks him to, creates a pair with the nearest friend and discusses about a subject.

\subsection{Mutual teaching}

It is a reading and discussing activity where the members of a group rarely play the role of the teacher

\subsection{Save the last word for me}

It is a discussion technique in which the students in turns lead the discussion

\subsection{Brainstorming}

It is a quick thinking technique, not a critical one. It is used to draw out as many ideas as possible and discuss them.

\subsection{Quick writing}

It is a quick reaction in written form toward a question or a requirement from the teacher.

\subsection{The table of questions}

This is where the students write down the questions to ask about the things they want to learn.

\subsection{Active learning}

It is the opposite of learning by heart. It is a kind of learning used to ask questions and research and a sort of internal learning.

\subsection{Group Learning}

It means the work in a group that makes the student responsible for the other's learning process. This kind of learning involves collaboration in learning. 


\subsection{Oriented reading activity}

It is lead by the teacher the reading in silence by the students through questions.

\subsection{Free writing}

Unstructured writing, focused on a subject and completed in a specific time, that aims to clarify the students what they have in mind and not to create declarations to be read by the others.

\subsection{The value line}

This is a collaborative activity where the students are put in an imaginary line according to their attitude: pro or against.

\subsection{Evaluation}

This is an activity covered in order to see what the students are learning and how they are learning it. The evaluation can be of different kinds like: informative, summarizing, or could be focused only on the content.

\subsection{Share a problem}

This is where the student must collaborate and prepare the questions about a material and then share them with another student from the other group.

\subsection{Unspotted talents}

This technique is applied by handing out pieces of papers and by asking the students to write down about something they like but the others have no idea. Meanwhile the students go round the class and try to find the student with the talent.

\subsection{The spider web}

This technique promotes unity. It is a good way to collaborate but including the attentive listening also.

\subsection{Comparative technique}

The comparative technique included in the learning process mainly aims the comparison and the communication of different types upon it. What we compare in school are: objects, phenomena, events, processes, etc.

\subsection{Venn's diagram}

The so called Venn's diagram is in fact a simple graphic (usually configured in two circles that are intercepted, in two squares which are intercepted, in two flags or in clouds that are placed above and make a neutral area which means that apart from the different features there are also common features. A wider way of comparison which would enable the communication that would include the entire class would be the structuring of the so called "mobile diagram" in the class.

\subsection{The technique "What do we know?, What do we want to know?, What did we learn?"}

This technique is also built upon communicative collaboration, usually in pairs or in groups of three students. They consult with each other and draw a list of outlines for the things they know about the subject or the assigned topic for discussion.

\subsection{Specialized roles in discussion}

The roles are selected in order to put emphasis to different aspects of the understanding. This technique enables the 
students to intentionally learn these roles through active practices. The method also teaches the student to be active in discussion, to take responsibilities for the other students' learning process and to put into practice the meaning of the subject.

\subsection{The tree of mind}

This is also a successful technique which could be used and can function even while discussing the homework. It consists in the summary made to the received knowledge and it has the unique value of reinforcement.

\section{Skillful Teachers for an Effective Active Teaching}

- $\quad$ Techniques that should be used more often in our schools nowadays

- $\quad$ The effective usage of the educational language

- The teacher's role is to know how to make the process of learning easier to every student. This means that firstly he should know how to create an appropriate atmosphere where every student feels good. A comfortable environment makes the process of learning be desirable and easy. On the other hand, every teacher can successfully develop a communicative learning. To achieve this well prepared and passionate teachers are required.

First of all the teacher must have the proper experience in his profession, apart the methodological and scientific knowledge he has. He should be commander of a wide and great variety of expressions for the thinking process, many of which have been accumulated due to the habit of reading many books, rich linguistic experiences, intellectual environment where he grew up or even because of the best professors who taught him. For this type of teacher the process of thinking unlike that of the student's is automatic. It should be kept in mind that this automatic way of thinking would not be a barrier to the fully understand the difficulties that the students have with the expressions of the process of thinking.

The teacher, part of the active-communicative process of the learning, is avoided from the center left to the student. He does not speak the whole time but knows how to be a good listener, so he has the listening skill of what the student communicates.

In fact isn't it the listening process one of the feelings that makes the student happier?

He wants to be in the center of the attention. But this feeling which is defined as on e of the most used ones is also one of the feelings less understood. We state this because listening to someone very carefully requires the ability of putting aside the notions learned before and being preoccupied to follow the flow of somebody's conversation that in fact if we are talking about the student it could be incorrect.

- Trying to involve a whole class in the active-communicative learning is not that easy if we keep in mind the different types of students and their skills or desires for different steps of the phases through the learning process is accomplished. When a teacher listens he has to select some signals in the class about the students who appear as impatient, who have no desire to wait, as from the lack of desire to listen in order to do something else, as in their impatience for being represented in an unfinished work which they eagerly wait to introduce and that do not manifest the same devotion to listen and follow the others while speaking.

These students often stimulate anxiety toward the teacher for the success of the lesson. The teacher should try to understand the students, though no-one has the ability to know all the details upon any child. The teacher should be sensitive toward every child's reality. At least he should have information about the kind of socio-economic culture the student cames from and especially the influences that are upon the student.

- The teacher should be vigilant and sensible but at the same time a teacher should also know how to identify strategies that would accomplish what is approved as acceptable a good number of students and on the other hand to create a respectful environment where everyone is listened from the others.

- Noticing the new models of the types of the learning process that represent students is also a very important aspect for the teacher. In fact the teacher during his work through years has the tendency to sharpen the vigilance to notice the mistakes. It is in fact in the nature of the profession to find everywhere mistakes. Anywhere he looks he finds mistakes. Following this method means speeding to do or perfect something. This kind of teacher has been inherited from one generation to another. It is not easy for the teacher to see and not find any mistake but in many cases it would be more effective not finding elements to correct even though it is not easy. But it would be more successful a learning process in which the vigilance to correct and what captures the student follow the same line and tries to acknowledge in details features of his character, "his 
weak points" that could be used for a better learning process.

- The teacher, who part of the active learning, successfully uses the stimulation. He continually practices expressions which include an urging vocabulary. An expression mostly used would be: try to imagine if..., try to think of another choice, etc, etc.

- The good teacher makes the communication a natural phenomenon even when he raises his voice in every activity performed on the board by trying to involve even those students that aren't attentive. At this point he realizes who has understood him and who is still unclear about the concepts explained. On the other hand he urges the student to think out loud by avoiding the stress of making a mistake with an expression or an activity. When it is necessary the teacher stops the written activity by asking the students to give a feedback of what they are doing and ask on or two students to say a few words. In this way the lesson becomes more natural, does not stimulate anxiety and the learning process is performed naturally.

\section{Which Would be Some Signs that Would Put the Teacher in the Role of an Actor Who Puts in Life a Very Detailed Plan that Enriches the Student with Information and Skill?}

- One sign is doing some Math with no material (for example a multiplication or a division, an addition, etc). Another is the imitation of some movements like: that of the wind, of the sun shine, of the storm, of a crashing, of a whirl, of an earthquake, etc. A good teacher who applies the communicative learning helps the student to make automatic the usage of the expressions of the educational thinking and not simply teach them how to use these expressions when asked during classes or when specific questions are asked. A good teacher aims to make the student automatically master these expressions and when this happens the student's brain will be free to perform other processes by starting from the reconstruction of details up to the reconstruction of special concepts and abstract idea within the content of the subject.

A successful teacher is that one who organizes the learning process as an intermediation between a task and a game which you need to accomplish properly. It is wonderful when the teacher creates and uses signs and specific movements which the student is accustomed to. They are of that kind that could be understood even by an occasional attendant (listener) but that could even not be understood all of them or at least not all of them have the same meaning as to the students that are already familiarized to them.

- To nod in order to give the idea that he is waiting to listen to a convincing argument

- To put his index finger toward the head in order to give the idea that he is waiting for the students to correctly interpret

- To make the gesture as having a phone to listen to by closing the three middle fingers and the thumb and the little one are opened in order to represent the telephone wires etc, to give the idea of different physical features

- To pretend like he is gathering imaginary ideas by warning the student about the process of the synthesis.

- To introduce through movements the sign of comparison between two circles formed by closing the thumb and the index finger together in each hand.

- To form the shape of the $\mathrm{K}$ letter in order to give the idea that it is now the moment to be classified.

- The communication among the students through groups (pairs or even bigger ones)

- The arm stretching as if putting into the balance of the scale in order to show appreciation

- The arm movement in the air firstly opened and then closed in a fist to practically show the application of the theoretical concept etc, etc

In a way all of these make what we call educational language that not only gives amusing features of the learning process but also takes away the anxiety that very often the word has, it creates a comfortable atmosphere and at the same time reinforces the expressions of the thinking process. On the other hand this is a way of getting away from the traditional forms with which the student and the teacher himself is bored.

\section{The Scheme of an Active-Communicative Class Designed by Successful Teachers}

The scheme of an active-communicative class would be composed of a teacher and students that stimulate the active thinking and learning. In this kind of class the discussions among the students and teachers are a lot. Often discussions are raised because of a student's or a teacher's question. The order, the type and the structure of the questions are important for the following discussions. They support higher complex levels in the critical thinking of the students. The 
questions are organized in a certain order when the ones of a lower order require detailed true answers (names, dates, places) and questions that treat more complicated questions like the relationships among the concepts or consequence of an event or a situation. The environment in the class depends in the collaboration (interaction) among the teacher and the students. Everybody's attitude is within a specific code. In these classes the teacher has always the role of inviting and motivating the students in discussions, in collaboration, in attendance. Through the assigned methods and professional attitudes he invites them to be part in the learning by assigning every student the place and role. So students and teachers are part of the collaboration. This kind of learning makes the student learn actively even in big classes.

Part of an active class is the understanding and collaboration.

The teachers make aware and lead the students toward a critical thinking. They show them the strategies of a critical thinking. They tell them which are some of the ways of critical thinking and they do so not by giving the idea that everything that comes out of their mouth is indisputable but by treating ideas in a hypothetical manner, conditioned and by motivating the respect of different points of view in a class. Students learn from each other through discussions. They not only master each other's ideas but also the way of thinking. On the other hand the teacher might doubt multiple ideas of the students and he also has to motivate the students to do the same with each other.

In the classes where the methods of an active-communicative learning are used exists an opening researching atmosphere. The teacher educates the usage of high standard questions from the students. So, not simply: "What?", "Where?", "When?", but "Why?", "What if?", "Why not?", etc when they analyze problems and take decisions. During the activities the students have specific roles with which they practice different types of thinking, they predict, gather information, ask questions about expected results. The teachers give the students more advice and instructions than critics and evaluations. The students are supported, but only as much as needed. The teachers pay attention to how the students operate, research, analyze, draw conclusions and how they express them properly. They try to examine the students of how to make it better and enrich their knowledge. The learning environment is opened, supporting and with no stress. The student does not hesitate to use another method, to implement a new idea, to individually think differently. The teacher tries to convince the student that even the unsuccessful attempt have value. They make them more willing and test their knowledge.

- The class management enables the student to alternate the individual work with that in a group. He does not hesitate to speak to his classmate, to compare his work with that of the others' and work together with the others to do a work or to brainstorm ideas, to consult with the others.

- The students' place can be changed any time it is needed. It depends from the method and the aim of the class, or the activity/activities being performed. For example we would put the students in placing schemes according to the aim and the way of how the class is organized:

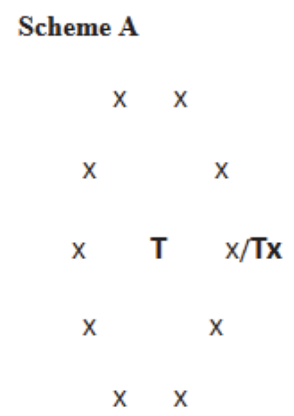

This kind of student placing $(X)$ would be effective for a discussion net. It would make the student to maximally be attentive and have full view of each other in order to follow the discussion. The teacher (T) can stand in the middle and give each student the right to discuss or can stand in the circle and be part of the discussion too. 


\section{Scheme B}

$\underline{\operatorname{xxxx} \quad \underline{x x x x}}$

$\underline{\operatorname{xxx} \quad \underline{x \times x}}$

$\underline{\operatorname{xxx} \quad \underline{x \times x}}$

$\mathbf{x}$

This placement is typical of a learning process when the students' interaction is not planned. The process consists in the listening of the teacher's word.

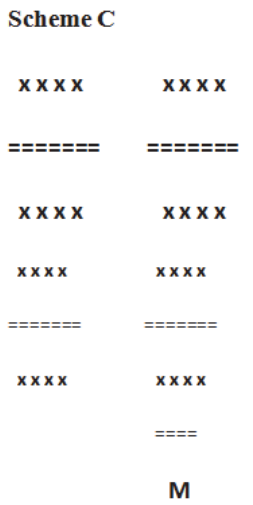

This kind of placement enables the collaborating work in small groups. Even though the teacher in the scheme is found in the front he is not immobile. He moves and monitors the group work and their results, he instructs the students, looks after the work performance.

\section{Conclusions}

1. The communicative teaching is nowadays the most successful learning model in our country. It is well known in our schools in the village and in the city though it is not practiced with the same performance and intensity.

2. In the university, the branches in which the students are prepared to become future teachers (according to the exact profile), it is required more methodological knowledge toward the learning process and the inspiration of a new learning process in the class. While they are getting so much scientific information, the future teachers have great difficulties in the sharing of the concepts according to modern methodologies. They often risk building a monotonous learning model where the credit simply goes to the sharing of the scientific concepts correctly.

3. The compilation of an educational language in which the teacher and the student are partners perfects the professionalism and the seriousness of the environment where you learn.

4. It is time for the lesson to be more a part of the student's pleasure rather than a rigid obligation, or a life difficulty. To make this happen it is required for "the game" to get a considerable place in the classes of our 9classes system. The concept "Game" should not be perceived only as an amusing line, a simple passing of time but as a great, varied lesson full of activities where everybody can be an active and successful part and a class free of anxiety about good results. Not all of them are so good, but everybody can do something well and 
build a successful future; not everybody is Einstein but it is known that even Einstein did not do so well at school despite his irreplaceable role in the science of Math. Successful teachers! Let us try to give our students the possibility to find themselves in what they do best.

\section{References}

Anderson, L.W.2000. Taxonomy for learning, teaching, and assessing: A revision of Blooms' taxonomy ofeducational objectives, complete edition. New York: Longman

Atwell, N:1987. In the middle: Writing, reading and learning with adolescents .Portsmouth, NH:Heineman

Amstrong.I.(2003), Thë multiple intelligences ofreading and writing:Making the wods come alive.Alexandria,VA:Association forsupervision andCurrriculum Development

Baloche, L.1997. The Cooperative classroom. New York: Prentice Hall

Benjamin, A.(2002). Differentiated instruction:Aguide for midleand high school teachers.Larchmont, NY: Eye on Education

Berman, S.(2001). Thinking in context:Teaching for open- mindedness and critical understanding, A:L:Costa

Bardhyl Musai, Psikologji edukimi (zhvillim, i, të nxënët, mësimdhënia), Pegi, Tiranë 1999

Calkins, L. M.200. The art of teaching Writing. New York:Longman

Dragoti Edmond, Adoleshenti, Hipokrati, Tiranë 1994

Dragoti Edmond, Psikologjia sociale,Toena, Tiranë 1999

Frye, N.1968. The eduvcated imagination. Bloomington, IN:Indianan University Press

Frye, P.2000, Pedagogy of the oppressed. New York: Continuum

Temple Charles, Crawford Alan, Sul Wendy, R.Mathews Samuel, Makinster James, Strategjitë mësimdhënies dhe të të nxënit aktiv për klasat mendimtare, ISBN 99943-766-5-9, Tiranë:CDE, 2006

Zwiers Jeff, Zhvillimi i shprehive të të menduarit në shkollë(për klasat 6-12), ISBN 99943-766-0-8, Tiranë: CDE, 2005

Rita Petro, Idriz Metani, Gjuha shqipe kl 8, Albas, 2010

Mendush Dërguti, Tomi Treska, Historia kl 8, Albas 2010

Rita Petro, Adelina Çerpja, Idriz Metani, Gjuha shqipe kl 9, Albas 2011

Mendush Dërguti, Sonila Boçi, Ledia Dushku,Historia kl 9, Albas 2011

Gregory,G.H.,\&Chapman, C(2002)Differentiated instructional strategies: One size doesn'tfit all. Thousand oaks,CA: Corwin

Gazeta "Mësuesi"8(25566)-tetor 2011, artikulli; Klasat eksperimentale

Gazeta"Mësuesi", nr 10(2568)-dhjetor 2011, artikulli; Të nxënit në projekte

Gazeta"Mësuesi"nr1(2569)-janar 2012, artikulli; Marrëdhëniet shkollë-prind

Gazeta"Mësuesi", nr6(2564)-qershor 2012, artikulli; Mësuesi misionar i ndryshimit, $f 18$

Gazeta"Mësuesi"nr 2 (2570)shkurt 1012, artikulli; Mjedisi, nxënësi, kurrikula në disa shkollla të vendit.

Gazeta"Mësuesi"nr 3(2571)-maj 2012, artikulli; Risi në komunikim; Si të komunikojmë me nxënësin

Gazeta"Mësuesi"nr 3(2571)maj 2012, artikulli: Kërkesat plërkualifikim të mësuesit, f14

Sarva Shiksha Abhiyan, Tamil Nadu in Partnership with, Active learning methodology, The School, Krishnamurti Foundation India, Chennai 